\title{
The Added Value of 'Instructional Simulation Practices' in Teaching International Relations and European Studies (IRES)
}

\author{
Mirela Alhasani (Dubali)
}

Epoka University

\section{Doi:10.5901/jesr.2014.v4n2p340}

\section{Abstract}

Instructional simulation practices represent a milestone in the educational methodology of most western universities by harmonizing equal balance between theory and practice. This paper will describe and assess the positive role that simulation practices offer towards better acquisition of the theoretical input during the undergraduate academic courses in the discipline of International Relations and European Studies (IRES). It will investigate and identify the need for academic integration of simulation activities in the core academic courses shedding light on the discrepancies of the current academic practice at in Albania, simultaneously, highlighting the advantages of instructional simulation towards in-depth learning versus surface learning of theory. The paper will be conducted through utilizing observation method with the contrastive textual analysis of the theoretical and empirical data, thus providing an argumentative exhibition and credible insights on the necessity of simulation practices to be intertwined with the academic compulsory curricula for better comprehension of the IRES theoretical concepts. It will draw on the successful experiences applied by international academic initiatives and upon their advantageous value to engage students in analytical learning, critical thinking and eloquence, building public speaking models, seeing the correlation between scientific knowledge and the tangible testable hypotheses on the empirical level. Unfortunately, the traditional Albanian higher education suffers from an unbalance between the massive theoretical input of the academic curricula - in our case study to the discipline of IRES - with the transfer, implementation and active learning of the theories of international relations and theoretical approaches to European Union. Therefore, incorporating and practicing instructional simulation at the undergraduate academic courses of IRES implies equipping the future political leaders, international negotiators, European delegates and prospective Albanian experts of international organizations with the scholastic knowledge and the relevant social interactive skills.

Keywords: simulation, international relations and European studies, active learning

\section{The Promotional Role of Simulations in Higher Education}

\author{
Tell me, I forget. \\ Show me, I remember. \\ Involve me, I understand. \\ Chinese Proverb
}

Although educators have been designing, applying, assessing and exploring educational simulations for around 50 years, yet, there are no commonly accepted definitions of an instructional simulation or of its many variations. Hertel and Millis have made an attempt to define educational simulations as 'sequential decision-making classroom events in which students fulfill assigned roles to manage discipline specific tasks within an environment that models reality according to guidelines provided by the instructor'. ${ }^{1}$ They emphasize in the first chapter the reasons why simulations further educational goals highlighting that simulations guarantee the traditional educational goals of knowledge transfer, skill development and the application of both knowledge and skills. Moreover, simulations teach the methods and strategies involved in the discipline, introduce students to significant organizations in the field, and provide more realistic interactions with other disciplines, and with people and organizations in the real world beyond the classroom. ${ }^{2}$

As the above top cited Chinese proverb implies, students tend to grasp concepts more easily when they are actively involved in the learning process; even more so, if they are assigned independent tasks to achieve the academic

\footnotetext{
${ }_{1}^{1}$ Hertel, J. P., \& Millis, B. J. Using simulations to promote learning in higher education: An introduction. Sterling, VA: Stylus Publishing, 2002, p 15

2 Ibid
} 
objective. This substantial role of simulation has already been identified and applied by western universities. For instance, the University of the West of England has undertaken the Simulation in Higher Education Project (SHE) which was shortlisted in the Outstanding ICT Initiative of the Year category of the Times Higher Education Awards in 2010. ${ }^{3}$ The ultimate goal of this project is to successfully relate theory to practice thus, catalyzing students' careers in the domains such as law, social work, planning, architecture, medicinal subjects, and many more.

Moreover, current developments in technology have offered opportunities to students to experience simulations on highly sophisticated cases. The emergence of highly up-to-dated technological infrastructure has been implemented to create a virtual world where students can experience events of the past and the present. ${ }^{4}$ The importance of this project has been emphasized by placing it under the framework of the E-learning Development Unit, which works with colleagues across the university to help with developments in curricula and delivery that use ICT. Similarly, Herbel and Millis accentuate the added value of simulations as problem-based units of learning that are set in motion by a particular task, issue, policy, crisis or problem. ${ }^{5}$ The implicit or explicit problem improvised in the simulation will be settled out by the students themselves through abundant density of interaction and negotiations.

Narrowing the research focus to the simulation practice in IRES, I bring as an early illustration the University of Maryland, USA, where ICONS evolved out of the Program in Global Issues established at this university in the early 1980s. The purpose of the program was to teach students about the "interdependence of global issues and the behavioral interdependence of nations" using simulation methodology. ${ }^{6}$ Likewise most other international universities, in this case study has been placed a great emphasis on integrating information technology into curricula giving rise to instructional technology and instructional in the IRES discipline.

Despite immense changes having undergone ever since its beginnings, the ICONS simulations have retained the same fundamental form of finding connections between the real world, the diplomatic arena over those problems where states have noticeable differences in interests and capabilities. Nonetheless, there remain gains to be achieved through cooperative action. Till the end of the Cold War the typical scenarios of these simulation activities encompassed 'high politics' level including START, NATO, Middle East, Sino-soviet Summit and Afghanistan. ${ }^{7}$ The end of the Cold War marked the launch of new simulation practices being transformed to the same rhythm of transformation in international relations. The exercises of educational simulation reflected these new evolvements focusing on issues like global warming, human security, environmental security, food security, global trading system, terrorism, European integration.

The Simulation of "International Relations of South East Asia" from the IRES domain will be an illustrative case study of the structural designing and empirical implementation. ${ }^{8}$ Referring to the said case study, students are divided into the role of diplomats from South Eastern Asian countries. They are provided with the preliminary insightful descriptions on the trade issues the region is being faced with. Despite the tangible rapid regional growth, the Association of Southeast Asian Nations (ASEAN) has been facing great internal challenges as economic disparities and equal access to basic services. Moreover, security and infrastructure deficiencies have already accelerated the region exposure to terrorism, crime, and public health crises. Currently, ASEAN has negotiating with Japan, China, and South Korea to create an ASEAN+3 pacts to increase global competitiveness. With increasing connections between countries, new cooperative approaches are needed to address the issues that after acquisition of the conceptual scenario outlining the preliminary negotiation issues to be discussed students will improvise round table discussions as representatives of their countries.

The instructor is accountable for administrating the simulation and providing feedback to the students. At the third stage - the process - students are provided with a brief scenario and they have to conduct independent research that will be represented at the negotiation simulation. The negotiation phase of the simulation itself lasts from 3 to five weeks. Through this interactive model students decide themselves on the negotiation directions, on the rhythm and climate of negotiations. ${ }^{9}$ Finally, regardless reaching a mutual agreement or not, the salience of the process is rather the in-depth

\footnotetext{
3 University of the West of England Available at the following link http://www.uwe.ac.uk/elearning/she/ Accessed on 26 March 2014 4 Ibid

${ }^{5}$ Hertel, J. P., \& Millis, B. J. Using simulations to promote learning in higher education: An introduction. Sterling, VA: Stylus Publishing, 2002, p 18

${ }^{6}$ Brigid A.Starkley \& Elizabeth L.Blake, "Simulation in international relations education", in Simulation Gaming: An interdisciplinary Journal of Theory, Practice and Research, volume 32, Number 4, December 2001, p 541-544

7 Ibid

8 University of Maryland, USA , "International Relations of Southeast Asia" Simulation http://www.icons.umd.edu/education/simulations /catalog/international-relations-of-southeast-asia\#.UzLm_PIdXOU Accessed on 26 March 2014

9 Ibid
} 
understanding of the process of international negotiations. The ultimate impact of simulation practices in international relations is boosting the development of elaborative and sophisticated representations of the international systems.

With regard To European Studies track, a best tailored academic module is given at the Undergraduate Program of Newcastle University in the UK, - entitled European Union: Decision-Making Simulation. ${ }^{10}$ By examining this module for our research purposes, it aims at making students familiar with the European Union institutions like the Commission, the European Parliament, and simulate how each representative member state makes decisions at the EU level. The course is designed in a very symmetric manner combining theoretical lectures on EU regulatory mechanism with the group discussion, paper writing and finally the EU simulation practical session by any team in the class. Moreover, the module has incorporated some video seminars to demonstrate EU parliamentary sessions from real group meetings, briefings and decision-making at high EU level. ${ }^{11}$

In brief, the rationale beyond any simulation practice is not only to provide students with immense knowledge on IRES but to enable them to research independently for the subject matter, to enhance their distinctive selective skills in voluminous sources, to build up team spirit and tolerance in committee meetings. Back to theatrical interpretation, Hertel and Millis maintain that much of what is successful outside of the academic environment can be extended to undergraduate instruction with careful curriculum design. ${ }^{12}$ The following section will be a brief chronicle of the higher education inspirational approach in Albania during the communist regime.

\section{Faulty Educational Philosophy in Communist Rule}

The inclusion of simulation into the academic connotes even more significance for the Albanian higher education which for half a century was totally under communist ideology constraints. Typical of dictatorships, the indoctrination of communist ideology was achieved through 'invasion' of brain by treating students and academic elite as 'mechanic parrots' in service of the political credo of that regime. While focusing upon the legacy of communist regime in higher education, ever since its establishment in 1944 the communist government prioritized in its agenda not only the national scale education, but in particular, its pure reflection of communist ideology. Indisputably, the sole goal of the regime was not only to wipe out illiteracy in the country, instead, to transmit to Albanian youth the principles of communism as interpreted by the party, and finally to educate the children of all social classes on the basis of these principles. ${ }^{13}$

For instance, the 1946 communist constitution made it clear that the regime intended to bring all children under the control of the state. All schools were soon placed under state management. At the same time, due to the lack of specialists in many fields of knowledge, a lot of young people were sent abroad to the countries Albania had diplomatic relations. In particular, the 1946 Reform on Education Law explicitly accentuated that the Marxist -Leninist principles would permeate all school texts. In addition, the utter Soviet conceptual orientation was consolidated by 1950s with concerns to both communist ideological propaganda and central government control. Even the three higher institutes founded in 1951; the Higher Pedagogic Institute, the Higher Polytechnic Institute and the Higher Agricultural Institute all were built up upon Soviet models. Significantly, the core school textbooks were absolutely Soviet translations engendering Soviet teaching methods, curricular and ideological mainstream. ${ }^{14}$

Undoubtfully the educational culture of higher education inherited by communist regime does not provide any incentives towards reconciliation with the Western higher education philosophy. The Special Report on the Future of Higher Education in Post-Communist States states that "universities in the post-communist states have not developed an atmosphere and environment that would allow their faculty and students to engage in the free exploration and development of ideas that is, or should be, characteristic of higher education"15.

Moreover, it highlights that critical thinking and open classroom discussions are often discouraged because most professors and students have, yet, - cited by the report, - a deeply embedded fear of being punished for saying what they

\footnotetext{
${ }^{10}$ Newcastle University, Undergraduate Study, Political Science track module on European Union: Decision- Making Simulation, 2014 Available at the following link and accessed in March 2014. http://www.ncl.ac.uk/undergraduate/modules/module/POL3063/

${ }_{11} \mathrm{lbid}$. For complete syllabus and assessment methods see the above link.

12 Hertel, J. P., \& Millis, B. J. Using simulations to promote learning in higher education: An introduction. Sterling, VA: Stylus Publishing, 2002

${ }^{13}$ Education in Albania during communism http://en.wikipedia.org/wiki/Education_in_Albania Accessed on 20 March 2014

${ }^{14} \mathrm{Ibid}$

${ }^{15}$ Special report, The Future of Higher Education in Post-Communist States, Interactivity Foundation and George Washington University , USA 2011, p7
} 
really think. ${ }^{16}$ Therefore, it strongly recommends 'the cultivating of freedom as the key to nourishing higher education and innovation in the post- communist states. Driven from the pedagogic interest, while tracing back the half a century lack of critical thinking in Albanian higher education system, it results that deeply flawed thinking has been rooted in the teaching methods, and consequently, the fostering of the independent thought and knowledge transfer into the students has been delayed.

Consequently, the academic elite itself demonstrated 'faulty models of pseudo-critical thinking as they simply propagandized flawed reasoning by playing the tune of the communist party ideology. In addition, the educational environment in universities does not retain any tradition conducive to critical thinking, interactive methodology and empirical role playing of the massive theoretical input. Hence, the cultivation of a culture of independent critical thinking, unbiased by any political ideology demands urgent curriculum amendments, and tailored interactive programs to enhance the independent analytical discourse.

\section{The Study of Interantional Relations Theory}

International relations theory entails the development of conceptual frameworks and theories to facilitate the understanding and explanations of the events and phenomena in the international arena. In addition, it offers analysis and information on the associated policies and practices. ${ }^{17}$ The international relations discipline was officially displayed after the World War 1 as a necessity to avoid future mass conflicts and, thus, aspiring to settle sophisticated international conflicts through peaceful negotiations and common understanding. ${ }^{18}$ Moreover, new conceptual frameworks and theories are required to improve diplomats' understanding of international policies and practices.

The major of International Relations and European Studies was first offered at the public university of Tirana in the beginning of the year 2000 within the department of philosophy at the Faculty of Social Sciences. This academic enterprise came as a response to the pressurizing need of Albania to prepare its future political elite, and in particular, its experts to conduct foreign relations to the best benefits of the country. Moreover, the country's aspiration for European Union membership constitutes an immediate incentive and prerequisite measure for the preparation of qualified human capital to guarantee the smooth adaptation and adjustment to European diplomacy.

International relations theories act as a pair of colored sunglasses, allowing the wearer to see only the salient events relevant to the theory. ${ }^{19}$. The three most popular theories treated by students in this discipline are realism, liberalism and constructivism. ${ }^{20}$ International relations theories can be divided into "positivists/rationalists" theories which focus on a principally state-level analysis, and "post-positivists/ reflectivists" ones which incorporate expanded meanings of security, ranging from class, to gender, to post-colonial security. Nevertheless, two positivist schools of thought are most prevalent: realism and liberalism though increasingly, constructivism is becoming a major influential mainstream. ${ }^{21}$

Moreover, students will be exposed to four strata of analysis: system level, state level, organizational level, and individual level. At the first stratum of theoretical analysis students examine state behavior in the vein of the overall international system level. They study the relationship between the two variables where the international system is the cause and the state behavior is the accordingly effect. Consequently, any alteration of the international system will automatically lead to adjustments and change of the individual state behavior. As a matter of fact, what constitutes the key variable is the power possessed by the state. This level of analysis might explain the relationship between two blocks during COLD war, and, currently the humanitarian interventions in Kosovo, where the system is perceived as unipolar with a most powerful state imposing the changes to other states' behavior. ${ }^{22}$

Furthermore, globalization trends might be well elaborated through the study of worldwide regimes, - rule governed activities within the international system. ${ }^{23}$ The twentieth century has mostly witnessed the rise of regimes to a global level phenomenon having states acknowledging a set of rules and institutions that attempt to facilitate the

\footnotetext{
16 Ibid, p $12-13$

17 What is International Relations Theory? Http://www.irtheory.com Accessed on 12 March 2014

$18 \mathrm{lbid}$

19 John Baylis, Steve Smith and Patricia Owens, The globalization of world politics, Oxford University Press, Fourth edition, 2008, p 4

20 Jack Snyder, 'One World, Rival Theories, Foreign Policy, 145, 2004, p.52

${ }^{21}$ Christian Reus-Smit, "Constructivism." Theories of International Relations, ed. Scott Burchill ... [et al.], Palgrave 2005, pp 209-216

22 Ibid http://www.people.vcu.edu/ wnewmann/468theory.htm

${ }^{23}$ Richard Little, "International Regimes", a book chapter in John Baylis, Steve Smith and Patricia Owens, The globalization of world politics, Oxford University Press, Fourth edition, 2008, p 298-299
} 
international relations in the world arena. ${ }^{24}$ In particular, by being exposed to theoretical literature, students and future diplomats or practitioners will better understand the complicated contemporary world politics being accumulated in huge piles of literature. They will also reflect and perceive the intriguing overlapping between politics and economy at high rank world politics. ${ }^{25}$ The economic interdependence and the free market regulatory systems will be provided through theoretical frameworks at regional level like the European Union single market, and at global level like The World Trade Organizations.

The state level analysis examines the foreign policy behavior of states in terms of state characteristics. For example, some researches in IR argue that all democracies behave in a common manner; democracies do not run into conflict with each other. Again students need to be facilitated to understand democratization process However, some other theoreticians take a special research interest precisely at the different behaviors of weak or strong states; states that comprise the core of European hegemony like Germany or France vs. states that are considered as the sole superpower assisting fragile democracies in tough regions, like the US. To illustrate this claim, the state level of analysis might explain the US intervention in Iraq as a function of the missionary quality of US foreign policy.

Organizational level analysis examines the way in which organizations within a state function to influence foreign policy behavior. States don't make decisions. Organizations bargain with each other to create a foreign policy that is a compromise between competing organizations. This level of analysis for example, might look at the Iraq war and try to explain it by examining the interests of the US military, the department of defense, the state department, and central intelligence agency.

Lastly, the individual level analysis focuses on people whose decisions make foreign policy. Scholars of IRES and students will have to study the psychology of the political leader in order to contemplate the decisive political role at world level politics. For instance, this analysis might look at the roles of different leaders. This level of analysis might explain World War II by examining the role of Hitler. It provides insightful argumentation on the distinctive role of prominent leaders like Gorbachev to mark the end of the Cold War. Furthermore, this level of analysis encompasses elaborative treatment of cognitive theories with the scope to reveal the correlation between leader's personality traits and foreign policy decision making. ${ }^{26}$

Definitely this enormous literature on the theoretical framework turns a challenging piece for the undergraduate students newly enrolled into the Bachelor programs. Being beginners in this major of study, they are desperately in need of practical and empirical contextual situations extracted from international relations and European Studies in practice. In other words, the knowledge transfer process requires exposure to tangible models, real international organizations by role playing accordingly the member states. Hence, the following section will concentrate on the promotional function of instructional simulation at higher education. It will examine from a comprehensive cross-disciplinary, yet theoretical and empirical spectrum, - the significant impact of instructional simulation in teaching IRES university programs in Albania.

\section{Applying Simulation in the Albanian IRES Domain}

The necessity for good, reasonable and critical thinking has become absolutely a most fundamental human need. In the contextual framework of political transformations in the early 1990s, the reform on higher education has been one of the most prioritized prerequisites for European integration agenda of any government in Albania. The educational reforming measures consisted of adaptation of the Western university model; placing the independent critical thinker-student at the center of the higher education programs. On the contrary, the previous Eastern educational philosophy placed the teacher on the educational spotlight imposing his/her believes to the students. Therefore, in the vein of academic adjustments towards Western norms, the interactive methodology has been extremely accentuated by the educational central authorities. These institutions along with international organizations and foundations were aware of educational philosophy in Albania: pure mechanic memorization of propagandistic facts by the students.

To illustrate the international contribution into Albanian academic reforming, - the Civic Education Project has been among the first actors. ${ }^{27}$ It was launched in Albania during the 1993-1994 academic years with one Visiting Faculty Fellow at Luigj Gurakuqi University in Shkodra. After one semester, this lecturer moved to the capital, Tirana, which

\footnotetext{
24 Ibid

25John Baylis, Steve Smith and Patricia Owens, The globalization of world politics, Oxford University Press, Fourth edition , p 3-4

${ }^{26}$ Professor Bill Newman, - Political Science Course. Available at http://www.people.vcu.edu/ wnewmann/468theory.htm Accessed in March 2014

${ }_{27}$ Civic Educaion project, Open society Institute, Headquarters in Budapest http://www.civiceducationproject.org/legacy/countries/see lindex.html Accessed in March 2014
} 
became the focal point of CEP activities during the next two years. CEP Albania operated at the University of Tirana, Aleksandër Xhuvani University in Elbasan, the Albanian Magistrates' School, and Luigj Gurakugi University. In the 200001 academic year, CEP expanded to three new departments - the newly created Department of Political Science, the Department of British and American Studies, and the Department of Journalism, all at the University of Tirana -and in particular it worked closely with Aleksandër Xhuvani University in Elbasan. 28

Apart from teaching in domains of law, political science, cultural studies and history the CEP fellows have made huge contributions to curriculum development, outreach activities attempting to build a cross-disciplinary approach to teaching, In addition to their teaching, CEP Fellows in Albania were active in curriculum development, outreach activities, and in bringing an interdisciplinary approach to teaching at these universities ${ }^{29}$ Every academic year CEP arranged national and regional project activities like in 2000 the Balkan Debate Forum in Sofia where students simulated parliamentary debates treating salient political themes.

In these academic initiatives students from Albania, Bosnia-Herzegovina, Bulgaria, Croatia, Greece, the Former Republic of Macedonia, Romania, Slovenia, Turkey and Yugoslavia simulated in parliamentary teams standing for the national interest of their representative countries. This was an attempt to compensate for the lack of International Relations study programs in most of these countries, and in our case study of Albania. ${ }^{30}$ Among other activities are to be mentioned the simulation entitled "South East European Economic Cooperation: Negotiation of a Free Trade Are on Agricultural Products". This simulation aimed at training South- Eastern European students to negotiate on a free trade area for agricultural products, hence playing the role of European Studies program familiarizing non EU member countries with the concept of free market economy, the abolishment of tariff barriers for the common European market not to the detriment of small or poor countries. ${ }^{31}$

Another simulation practice organized by the CEP program in Albania was the Parliamentary Debate Tournament held in Belgrade in February 2002 with the participation of university students from the region. The simulation activity again reshaped the bargaining skills even among post-ethnic conflicts areas aiming to ameliorate the political climate and reduce future ethnic clashes among young generations. However, this several days negotiation simulations cannot substitute for the academic theoretical course on Peaceful Settlement of Conflicts. Regardless the limited theoretical lecturer input, these simulations were excellent empirical practices that attempted to expose Balkan students to real political science scenarios, to role models and decision-making dilemmas anticipating their professional challenges in the future.

A second practical illustration is the activity called Model European Union Albania which has performed three simulation practices by now and, from 3th of May to 11th of May 2014, it will be holding the fourth one. This European simulation is supported by the European Commission through the Youth in Action Program. ${ }^{32}$ Its principal goal is the promotion of youth participation in democratic processes, familiarization and importance of the European Parliament elections, and above all, active citizenship in the decision making process. In lieu of the MEU 2014, students will play the roles of Ministers of the Member States of the EU, European Parliament MEPs, EU Commissioner and journalists. ${ }^{33}$ Through role playing students will gain independent researching skills, will set foot on ground in terms of international organizations behavior and performance. Finally, they will take the opportunity to put into practice their vast theoretical knowledge on European Union and institutionalism literature. This program by European Commission aims to boost success at Political Sciences, Diplomacy and European Legislation students in Albania by offering an improvised forum to communicate freely, to take decisions and to evaluate a member state responsibility.

However, this one-week annual simulation does not provide adequate space for the outnumbered students of International relations and European Studies departments at the numerous universities of Albania. Therefore, this Model European Union simulation should be integrated into the academic curricula of the Bachelor programs. This successful model should be taken as an illustration by professors who lecture the fields, thus, providing exposure and access to all

\footnotetext{
$28 \mathrm{Ibid}$

${ }^{29}$ The author of this research paper, I have been an active member of this project ever since its first launch in Albania till graduation from Central European University in 2004.

${ }^{30}$ As the author of this article I draw on my personal experience as a student where I participated as Albanian representative in several activities of the CEP program at Alexander Xhuvani University in Elbasan, Albania.

${ }^{31}$ Again I refer to my personal experience as active participant and representative of Albania in this international simulation.

32 Model European Union Albania - Accessed in March 2014 http://www.mladiinfo.eu/blog/2014/03/28/model-european-union-at-theeuropean-week-in-tirana-albania/

33 Model European Union http://www.mladiinfo.eu/blog/2014/03/28/model-european-union-at-the-european-week-in-tiranaalbania/Hixzz2xWWoiMEY
} 
students to see how international organizations work in practice. Through placing these simulation practices, which are introduced successfully by the CEP program of Open Society Institute and European Commission, in the compulsory curriculum programs the natural harmonization of theory with tangible practice will be achieved par excellence.

Furthermore, simulation academic courses have proved conducive to active and critical learning in other crucial majors of study like Economics, Business Administration and Management, Marketing, and Finance. I refer to Business Communications: International Case Studies in English by Cambridge University press which is a book and a course conveyor at the same time. ${ }^{34}$ This case study method-book is based upon the approach applied at Harvard Business School making the shift from teacher-centered to student-centered. The students are required to reveal their knowledge of business to stand for their positions in the case studies, to expand their repertoire of communications by developing team work, group work, and critical-analytical problem solving skills. In addition, each case is a complete unit and is pedagogically fragmented to bring a logical cohesion in the solving of the case..$^{35}$ It consists of a cultural background part, a description of the contextual environment, discussion questions before case activity and role play-division, written exercises to follow up the case and, finally the vocabulary with support materials. ${ }^{36}$

Similarly, the conceptual framework and ultimate objective of instructional simulation in IRES fall into the same pillars. As already emphasized in the previous sections, students gain vast accumulated knowledge through theoretical core courses of the academic programs. Simulations like business case studies improvising will bridge the successful knowledge transfer to empirical level. Their added value to enhancement of academic interaction, boosting of active learning and critical and analytical thinking merges as the most immediate academic measure to be taken officially in the core curriculum.

\section{Conclusion}

This paper investigated and examined the need of Albanian higher education to harmonize theoretical input with instructional simulation practices. It first provided a theoretical framework on the added value of simulations in higher education in general. Then, it narrowed its focus on the discipline of International Relations and European Studies highlighting the intrinsic sophisticated correlation of the massive literature thus identifying the need for practical role playing to better grasp the abstract theory. Next, the communist indoctrination legacy was analyzed to reinforce the huge gap of independent critical thinking by students and scholars as ideal models. Afterwards, the research described the experience of simulation practices in Albania. They have mostly been sporadically preformed through the open Society initiate at Civic Education Project and, the current one the Model Europeans Union supported by European Commission.

However, despite shaping the warming up communicative environment, these one-week international simulations turn to be limited and insufficient based on the following already exhibited argumentation. First, though relatively a new discipline in Albanian higher education, the literature on IRES has grown dramatically fast likewise the accelerating pace of political, social, economic and cultural transformations at the global scale. Therefore, students of this major of study find themselves overloaded and bombarded with a massive flow of information and theoretical concepts. Students have to assess those theories by referring to the relevant historical evidence that supports them. Unlike natural sciences, in social sciences scholars, students and practitioners cannot conduct experiments because their subject matter is about nations: Instead they can interpret these concepts through usage of historical literature and contemporary case studies.

As argued by many academicians and scholars the negative legacy of communism ideology embedded deeply in the heart of university system, demands for practical contextual learning through instructional simulation as an indisputable tool to promoting analytical understanding and interpretation of the theory. To sum it up, instructional simulation will serve as the best empirical mechanism to engage students in deep learning rather than a classical lettera per lettera theoretical interpretation of the international relations and European events. Academic courses pursuing the structural and scope framework of NATO Youth Summit, the Model European Union Youth Simulation, the Arab League of Nations Simulation, the United Nations Simulation Sessions, should become a mandatory integral part of the academic curriculum for IRES undergraduate programs in Albanian universities.

\footnotetext{
${ }^{34}$ Drew Rodgers , Business Communications : International Case Studies in English, Cambridge University Press, 2002, p VII

35 Ibid, $p$ VIII

${ }^{36}$ Ibid, $p$ IX
} 


\section{References}

Christian, Reus-Smit. "Constructivism", Theories of International Relations, ed. Scott Burchill [et al.], Palgrave 2005 Drew, Rodgers. Business Communications: International Case Studies in English, Cambridge University Press, 2002

Hertel, J. P., \& Millis, B. J. Using simulations to promote learning in higher education: An introduction. Sterling, VA: Stylus Publishing, 2002

Snyder, Jack. "One World, Rival Theories", Foreign Policy, 145; ABI/INFORM Glob 2004

Starkley, Brigid \& L.Blake, Elizabeth. "Simulation in international relations education", in Simulation Gaming: An interdisciplinary Journal of Theory, Practice and Research, volume 32, Number 4, and December 2001

Professor Bill Newman,- Political Science Course http://www.people.vcu.edu/ wnewmann/468theory.htm Accessed in March 2014

Newcastle University, Undergraduate Study, Political Science track module on European Union: Decision-Making Simulation, 2014 http://www.ncl.ac.uk/undergraduate/modules/module/POL3063/

Civic Education Project in Albania http://www.civiceducationproject.org/legacy/countries/see/index.html Accessed in March 2014

University of Maryland, USA, "International Relations of Southeast Asia" Simulation http://www.icons.umd.edu/education Isimulations/catalog/international-relations-of-southeast-asia\#.UzLm_PldXOU

What is International Relations Theory? Http://www.irtheory.com Accessed in March 2014

The Model European Union Youth Simulation http://www.meu.al/2014 Accessed in March 2014

http://www.mladiinfo.eu/blog/2014/03/28/model-european-union-at-the-european-week-in-tirana-albania/\#ixzz2xWWoiMEY 